\title{
Influence model problem based learning against critical thinking skills in learning thematic integrated class IV
}

\author{
Yulia' ${ }^{1}$, Farida ${ }^{2}$, Yuni $^{3}$ \\ ${ }^{123}$ Universitas Negeri Padang, Padang - Indonesia, (yjnazri08@gmail.com)
}

\begin{abstract}
The purpose of this study was to investigate: the effect ofmodels problem based learning to the critical thinking skills of learners in an integrated thematic learning. This research is a kind of quasi-experiment. The population is all learners in elementary Nanggalo Padang and the sample are learners class IVA and IVB as many as 52 people. The sampling technique in this research istechnique. purposive sampling Data from the research results obtained from tests of critical thinking skills. The results showed that the learning model of problem based learning affects the critical thinking skills of learners in an integrated thematic learning.
\end{abstract}

Keywords: problem based learning, critical thinking skills, thematic integrated.

\section{Introduction}

Curriculum 2013 is designed to prepare beings who have the ability to live as individual nd citizens who believe, productive, creative, innovative, and effective personal able to contribute to society, nation and the state. Thematic learning as learning models include one type / kind of on integrated learning model. Thematic learning is basically an integrated learning model that uses the theme to associate some subjects that can provide meaningful experiences for learners (Sufairoh, 2016: 117).

Thematic learning whose implementation is no longer separated it into a unity and coherence. In line with the opinion of Tyler (in Jacobs, 1989: 25) who had suggested that separate learning more integrated, because if the experience is not associated, learners will develop learning activities that are not related to one another and are not effective in dealing with ordinary life day.

In thematic learning learners gain direct experience and are trained to find their own variety of knowledge learned in a holistic, meaningful, authentic and active as well as help the efforts of learners to acquire knowledge and critical thinking early learners in learning.

Based on the opinion of Ennis (2011: 1), critical thinking is"criticalthinking is reasonable, reflective thinking that is focused on Deciding what tobelieve or do". According to this definition, emphasizing critical thinking sensible way of thinking and reflective. Critical thinking is a thinking skills learners 
need to be developed in schools, in this case the teacher is expected to realize learning to enable and develop critical thinking skills in learners. Each learner has a critical potential, but the problem is how to develop that potential through a learning process in the classroom.

Critical thinking skills of learners can be trained by learning that requires learners to explore, inquiry, discovery and solve problems as well as through learning in small groups to apply theapproach scaffolding then demanding task of cognitive and metacognitive strategies learners. So basically for learning, learners are required to be active. However, some research shows that learners tend to take knowledge from the teacher. It shows that the critical thinking skills of students have not been trained optimally.

This fact is corroborated by the statement Corebima (2005: 1), that the educational institutions in Indonesia, especially at primary school level and secondary schools, teachers are still less attention to aspects of thinking skills in the learning process.

As has been noted earlier that the critical thinking skills and creative learners can be trained by learning that requires learners to explore, inquiry, discovery and solve problems so that one model of learning that can be assumed to be able to improve the critical thinking skills of learners that is model-based learning problem.

In line with the opinions Allchin (2013: 3), Another way to engage students in their own learning is posing problems for students to solve. Reviews These embody the rationale for learning, the which is elsewise typically based solely on the authority of the instructor (or, by default, a textbook). Typically, such problems are rooted in cases (Although they need not be, or the case itself may be quite minimalistic). Merely cases may function as narratives, or as a setting forknowledge.

This is because that the problem-based learning, enabling learners to develop the knowledge, abilities, and skills in full in an atmosphere of open, democratic, and capable of producing knowledge that is really meaningful (Hinderasti, 2013: 5).

It is strengthened by an explanation Permendikbud 81A (2013: 4) and Kemendikbud N0. 20 (2016: 46), to strengthen and encourage the ability of learners in learning, learning models necessary for their implementation. The learning model used in the implementation of the curriculum in 2013 is discovery learning (DL), problem based learning (PBL) and project based learning(PPA).The learning model is designed and implemented, so that the critical thinking skills of learners can be achieved in line with expectations.

Crowley (2015: 17), students who are under the PBL had instructed Become more intrinsically motivated, demonstrate greater levels of interest, showcase more independent learning, report higher levels of self-efficacy, have better-developed metacognitive skills. In his research shows that, the students are instructed under the PBL to be more intrinsically motivated, demonstrate a higher level of interest, displaying a more independent learning, self-reported levels higher progress, has developed metacognitive skills better. The development of this power can increase the level of achievement of higher

Based on exposure that have been described, then the model of Problem Based Learning (PBL) is deemed appropriate learning strategies to empower students' critical thinking skills. This is because in its application, any syntax Problem Based Learning (PBL) support and complement each other in the empowerment of learners' critical thinking skills. Based on these descriptions, it is necessary to do a study evaluating the effect of the model of Problem Based Learning (PBL) and motivation to learn about critical thinking skills of learners. 
Abdul Kadir, NH Abdullah, E. Anthony, B. and R. Kamarulzaman Mohd Salleh (2016: 4), the problem solving process, the which is central within a PBL environment, was guided by a framework where students learn to explore and analyze problems systematically. This enables students to be proactive and expand Reviews their existing knowledge bases. Also Students use various sources of information from their textbooks and others in informal discussions with peers. the which enable them to integrate knowledge across disciplines and approaches. Other than that, PBL Provides channels for students to experience authentic problems by having authentic problems to be solved, students are more Involved in the learning process. Therefore, students are usually more innovative and creative in their problem solving approach.

This is reinforced by the opinions Trianto (2014: 69), Problem Based Learning is believed to be able to develop the ability krativitas learners, either individually or as a group, because almost every step requires active learners in learning. In line with the opinion of Alfred Olufemi Fatade, David Mogari, Abayomi Adelaja Arigbabu (2013: 1), which states that, PBL approach made students more creative, act purposefully, think rationally and prompted teachers to know when and how to apply scaffolding during the course of classroom teaching.

This study can be considered the use of the model of Problem Based Learning for material or other subjects as well as the need to overhaul the motivation of learners that are not considered equal to all conditions. This study is also expected to be used as a variation model of learning for teachers to empower critical thinking skills of students in learning.

\section{Method}

This type of researchused in this study is a quasi-experiments aimed to determine the effectmodel of Problem Based Learning of thecritical thinking skills. The research was conducted at SDN 09 Padang Surau Tower in odd semester 2017/2018 academic year are planned for the second week of October to the beginning of November 2017. The study population was all students at SDN 09 Surau Tower Padang while the study sample was grade IV by taking a sample of two classes of 52 people consisting of 26 students in the class IVA as control classes and 26 students in the class IVB as an experimental class. Sampling with purposive sampling because it has a homogeneous member or element. The independent variable in this study is the Problem Based Learning and learning directly, while the dependent variable is the ability to think critically. The research design used in this study is adesign $2 \times 2$ factorialcontrol. The instrument used to obtain the data in this study is a test of critical thinking skills in an integrated thematic learning. Instruments assessed by the competent validator which includes professors and teachers at the school and is tested against a sample of respondents outside the classroom.

\section{Results and Discussion}

Model Problem Based Learning affect the critical thinking skills of learners.

Table 1. Average Value Critical Thinking Skills class and Control Experiment

\begin{tabular}{|c|c|c|c|c|}
\hline Class & $\mathrm{N}$ & $\bar{x}$ & X Min & XMin \\
\hline Experiment & 26 & 67.55 & 84.83 & 46.88 \\
\hline Control & 26 & 64.66 & 84.83 & 46.88 \\
\hline
\end{tabular}

Based on the exposure of Table 1 above shows that the average results of tests of critical thinking skills of learners based learning model used in both classes: experimental class had an average total of 67.55 and with a control class has an average of 64.66 . The measurement is stated that the learning 
model used in the study affect the competence of learners, especially in the critical thinking skills of learners in an integrated thematic learning. This is supported by research conducted by Tomi Utomo (2014: 1) argued that an understanding of the concept of learners are given a problem-based learning (PBL) is better than the understanding of the concept of learners who are given conventional learning.

One of the factors that most influence on the critical thinking skills of learners is a modellearning Problem Based Learning. Model Problem Based Learning implemented in five stages. Instage first theof the orientation of students in trouble. At this stage the teacher explains the purpose of learning, explained the logistics required and motivating the students to be actively involved in solving the problem. This activity aims to train students to concentrate. Both organizing learners into groups, where the teacher divides the learners into groups of heterogeneous and distributed literature teacher and LDK, and ask each group to understand the material. Third, guiding the investigation group. Teachers encourage students to participate gather the appropriate information and explanations in solving problems. Fourth, development and present the results of the work, which the participants were asked to submit material that has been understood alternately on the representation of each group. Fifth analyze and evaluate the problem solving process in which other groups can provide feedback to the group presentation. This is inversely proportional to the discussion of the method of learning where the teacher of the lesson learned lesson without requiring a learner's thinking.

Both classes were given tests in the form of critical thinking skills tests. In this activity, learners have the opportunity to empower their thinking ability. According to Susanto (2013: 121) critical thinking skills are the activities of thinking about ideas or ideas relating to a given concept or problem presented. Critical thinking is also understood as activity in analyzing ideas or ideas in more specific or profound ways, distinguishing them sharply, choosing, identifying, learning, and developing them in a more perfect way. Cognitive-based skills of understanding involve high-level thinking skills, such as problem solving, critical thinking, creative, and decision-making (Berns \& Erickson, 2001). critical thinking is the process of seeking, obtaining, evaluating, analyzing, balancing, and conceptualizing information as a guide to developing and developing risk (Yildirim and Ozkahraman, 2011). Thus, learning to understand is synonymous with the learning of thinking skills one of which is the critical thinking ability of the students.

Based on the above description of the study there is a difference in the formation of knowledge that teachers do. This difference is considered to support the results of research indicating that the problem-based learning model is effective for critical thinking skills of learners rather than learning by direct learning. Problem solving is a skill that can be taught and learned (Harlinda, 2014:5). Based on the observation of this learning activity shows that give a big or dominant influence to improve the critical thinking ability of learners. The influence of larger learning methods is considered to improve critical thinking skills. Furthermore, from the data analysis found that there are significant differences in the learning phase in the classroom.

\section{Conclusions}

The learning model Problem Based Learning affect thechildren critical thinking skills of participants in an integrated thematic learning. The effect is seen, on the competence of learners khuusnya on critical thinking skills that are higher than the critical thinking skills of students in learning classroom discussion on the controls. 


\section{Acknowledgments}

Actually, this article is part of my thesis. Then, I would like to thank my mentor (Dr. Farida F, M.Pd., M.T., and Dr. Yuni A, M.Si.) who supported me to do the research. It all inspires me to publish my studies. I would also like to thank all the leaders at SDN 09 Surau Gadang Kota Padang, and academics who have shared ideas and information about the world of Education. Last but not list, I would like to thank all the students at SDN 09 Surau Gadang Kota Padang, who was involved in this research.

\section{References}

Abdul Kadir, NH Abdullah, E. Anthony, B. \& R. Kamarulzaman Mohd Salleh1. (2016). Does the Problem-Based Learning Improve Problem Solving Skills? A Study among Malaysian Business undergraduates at Premier Technical University Z. Journal: International Education Studies Vol. 9 No. 5; 2016. ISSN: 1913-9020 E-ISSN 1913-9039.

Alfred Olufemi Fatade, David Mogari, Abayomi Adelaja Arigbabu. (2013). The Effect of Problem Based Learning on senior Secondary School Student's Achiefments in Furthier Mathematics. Napocensia Didaktica journal Acta. Vol 6, No. 3, 2013. ISSN: 2065-1430.

Allchin, Douglas. (2013). Problem and Case-Based Learning in Science: An Introduction to distinctions, Values, and Outcomes. Journal: CBE-Life Sciences Education Vol. 12, 2013 ISSN: 364-372.

Berns, R. G., \& Erickson, P. M. (2001). Contextual teaching and learning: Preparing students for the new economy. Columbus, $\mathrm{OH}$ : National Dissemination Center for Career and Technical Education. Retrieved August 14, 2017 from (www.cord.org/.../nccte highlight05-contextualtea. pdf).

Crowley, Brittany M. (2015). The Effect of Problem Based on Mathematics leraning of Elementary Student Achievement AcrossTime.Faculty of the Department of Psychology Westem Kentucky University: Bowling Green,Kentucky.

Ennis, RH (2011). The Nature of Critical Tingking: An Outline of Critical Thingking Dipositions and Abilities. Share at the Sixt International Conference on Thingking at MIT, Cambridge, May July 1994 (last Revised May 2011). Retrieved August 30, 2017 from http://faculty.Education.illinios.edu.rhennis/documents/thenatureoofCritical Thingking51711 000.pdf.

Harlinda. (2014). Critical Thingking Analysis in Solid Ways Matematical Problem Based on Polya The Quadrate Square Requitment. Journal: Electronik Pembelajaran Matematika Vol. 2, No 9, November 2014. ISSN: 899-910.

Hinderasti. (2013). Effect of Problem Based Learning Model with Experimental Method of Mechanical Roundhose accompanied Diagrams and Mind Map to Biology Learning Outcomes in terms of Learning Styles and StudentMotivation.Journal: Bioedukasi Vol. 6, No. 2. August 2013. ISSN: 1693-2654.

Jacobs, D, Ary, LC (1989). Introduction to Educational Research.Translation by Arief Furchan. 1982. Surabaya: National Business.

Jumaisyaroh, Tanti. (2015). Improved critical thinking skills and independent learning mathematical junior high school students through problem-based learning. Journal: AdMathEdu Vol.5 No.1. June 2015. ISSN: 2088-687X.

Permendikbud. (2013). Regulations On Application of Scientific Approach No. 81 A. Jakarta: Kemendikbud

Permendikbud. (2016). Curriculum 2013 Learning Tool PERMEN 20-24. Jakarta: Kemendibud.

Susanto, A. (2013). Theory of Learning in Primary School. Jakarta: Kencana. 
Trianto. (2014). Designing Innovative Learning Model, Progressive, andContextual. Jakarta: Prenamedia Group.

Utomo, Tomi. (2014). Effect ofModel Problem Based LearningTowards Understanding Concepts and Creative Thinking Skills Odd Semester Grade VIII SMPN 1 Sumbermalang Situbondo Academic Year 2012/2013. Journal of Educational UNEJ Volume I (1): 5-9

Yildirim, B \& Ozkahraman, S. (2011). Critical Thinking in Nursing Process and Education. International Journal of Humanities and Social Science. Vol 1, No 13, Hal 257-262. 